\begin{tabular}{c} 
Tersedia online di: http://ejournal-balitbang.kkp.go.id/index.php/bawal \\
e-mail:bawal.puslitbangkan@gmail.com \\
BAWAL WIDYA RISET PERIKANAN TANGKAP \\
Volume 9 Nomor 2 Agustus 2017 \\
p-ISSN: 1907-8226 \\
e-ISSN: 2502-6410 \\
BAWAL \\
Nomor Akreditasi: 620/AU2/P2MI-LIPI/03/2015 \\
\hline \hline
\end{tabular}

\title{
KOMPOSISI, SEBARAN UKURAN DAN HUBUNGAN PANJANG-BERAT BEBERAPA JENIS IKAN PETEK (LEIOGNATHIDAE) DI TELUK JAKARTA
}

\section{COMPOSITION, SIZE DISTRIBUTION AND LENGTH-WEIGHT RELATIONSHIPS OF SOME PONY FISHES (LEIOGNATHIDAE) IN JAKARTA BAY}

\author{
Setiya Triharyuni*1, Andria Ansri Utama ${ }^{1}$, Naila Zulfia ${ }^{2}$ dan Priyo Suharsono Sulaiman ${ }^{1}$ \\ ${ }^{1}$ Pusat Riset Perikanan, Jln. Pasir Putih II, Ancol Timur, Jakarta Utara- 14430, Indonesia \\ ${ }^{2}$ Loka Penelitian dan Pengembangan Mekanisasi Pengolahan Hasil Perikanan, Jl. Imogiri Barat. KM 11.5 Jetis, Bantul- \\ D.I. Yogyakarta, 55781-Indonesia \\ Teregistrasi I tanggal: 26 Agustus 2016; Diterima setelah perbaikan tanggal: 09 Agustus 2017; \\ Disetujui terbit tanggal: 21 Agustus 2017
}

\begin{abstract}
ABSTRAK
Perairan Teluk Jakarta memiliki potensi perikanan tangkap bagi masyarakat daerah pesisir Jakarta. Berbagai jenis ikan tertangkap pada perairan ini. Ikan petek (Leiognathidae) di Teluk Jakarta merupakan salah satu jenis ikan demersal yang cukup banyak tertangkap. Keragaman jenisnya mencapai setengah dari jenis ikan petek diseluruh Indonesia. Selama penelitian telah ditemukan sebanyak tujuh jenis ikan petek dati tiga jenis genera, yaitu jenis L. splendens, L. equulus, S. ruconius, G. achlamys, L. fasciatus, L. decorus and L. bindus. Penelitian ini ditujukan untuk mengetahui pola pertumbuhan ikan petek di perairan Teluk Jakarta. Model yang digunakan adalah model linear regresi dengan menggunakan metode kemungkinan maksimum. Model ini digunakan untuk mendapatkan estimasi maksimum likelihood (MLEs) parameter pertumbuhan ikan petek. Hasil analisis menunjukkan bahwa tidak terdapat faktor koreksi bias yang diperlukan dalam mendapatkan parameter pertumbuhan ikan. Hasil perhitungan memperlihatkan pola pertumbuhan ikan jenis L. splendens, L. equulus, $S$. ruconius dan $G$. achlamys bersifat alometrik negatif, sedangkan jenis ikan $L$. decorus dan $L$. fasciatus bersifat alometrik positif. Perkiraan ukuran panjang ikan pertama tertangkap berada dibawah ukuran pertama matang gonad $(\mathrm{Lc}<\mathrm{Lm})$, kondisi ini mengindikasikan perikanan mengarah pada growth overfishing.
\end{abstract}

Kata Kunci: Petek; panjang-berat; log-alometrik; koreksi bias; growth overfishing

\section{ABSTRACT}

Pony fish (Leiognathidae) one of dominated catches of fisheries in the Jakarta Bay. There is 7 species of pony fish found in the Jakarta Bay (about an half of total species of pony fishes in Indonesia), namely Leiognathus splendens, L. equulus, S. ruconius, G Achlamys, L. fasciatus, L. decorus and L. Bindus. This reseach aims to examine the growth pattern of pony fishes in Jakarta Bay. Linear regression models used to obtain maximum likelihood estimation (MLEs) fish growth parameters. This model showed that there is no bias correction factor needed in getting the growth parameters. The calculations show that the growth pattern of $L$. splendens, $L$. equulus, S. ruconius and $G$ achlamys were negative alometric, while L. fasciatus and $L$. decorus were positive alometric. It also reveled that the length at first capture was smaller than length at first maturity which indicates growth overfishing of this fisheries

Keywords: Pony fish; length; weight; log-allometric; bias-correction; growth overfishing

\section{PENDAHULUAN}

Perairan Teluk Jakarta memiliki potensi dalam kegiatan perikanan tangkap di daerah Jakarta khususnya aktivitas perikanan yang mendaratkan hasil tangkapannya di Tempat Pelelangan Ikan (TPI) Cilincing. TPI Cilincing merupakan tempat pelelangan ikan yang terletak di Jakarta Utara. Terdapat berbagai jenis ikan yang didaratkan di TPI tersebut. Salah satu jenis ikan yang banyak didaratkan adalah ikan petek. Ikan petek merupakan jenis ikan demersal yang masuk dalam famili Leiognathidae. Penyebaran ikan petek ini sangat luas, yaitu berada di perairan tropis 
dan subtropis. Famili Leiognathidae di Indonesia terdapat tiga genera, yaitu Leiognathus, Secutor dan Gazza (Pauly, 1977). Jenis ikan petek di Teluk Jakarta cukup banyak, bahkan jenisnya mencapai setengah dari jenis ikan petek di Indonesia (Burhanuddin et al., 1980).

Analisis mengenai hubungan panjang-berat yang dapat digunakan untuk mempelajari pola pertumbuhan ikan. Pertumbuhan ikan ini secara umum didefinisikan sebagai pertambahan ukuran, khususnya panjang dan berat (Mazlan \& Seah, 2006; Kishakudan \& Reddy, 2012). Persamaan hubungan panjang-berat ikan dimanfaatkan untuk mendapatkan ukuran berat ikan melalui panjangnya dan menjelaskan sifat pertumbuhannya. Dengan kata lain bahwa berat dapat dianggap sebagai suatu fungsi dari panjang. Hubungan panjang dan berat hampir mengikuti hukum kubik yaitu berat ikan sebagai pangkat tiga dari panjangnya. Hubungan ini dapat dimanfaatkan untuk menduga berat melalui panjang (Effendie, 1997).

Hubungan panjang berat memiliki persamaan $W=a L^{b}$. Model ini merupakan model persamaan nonlinear yang umum digunakan untuk memprediksi berat ikan dari panjang ikan. Perkiraan kemungkinan maksimum dari skala (a) dan bentuk (b) parameter pada persamaan tersebut

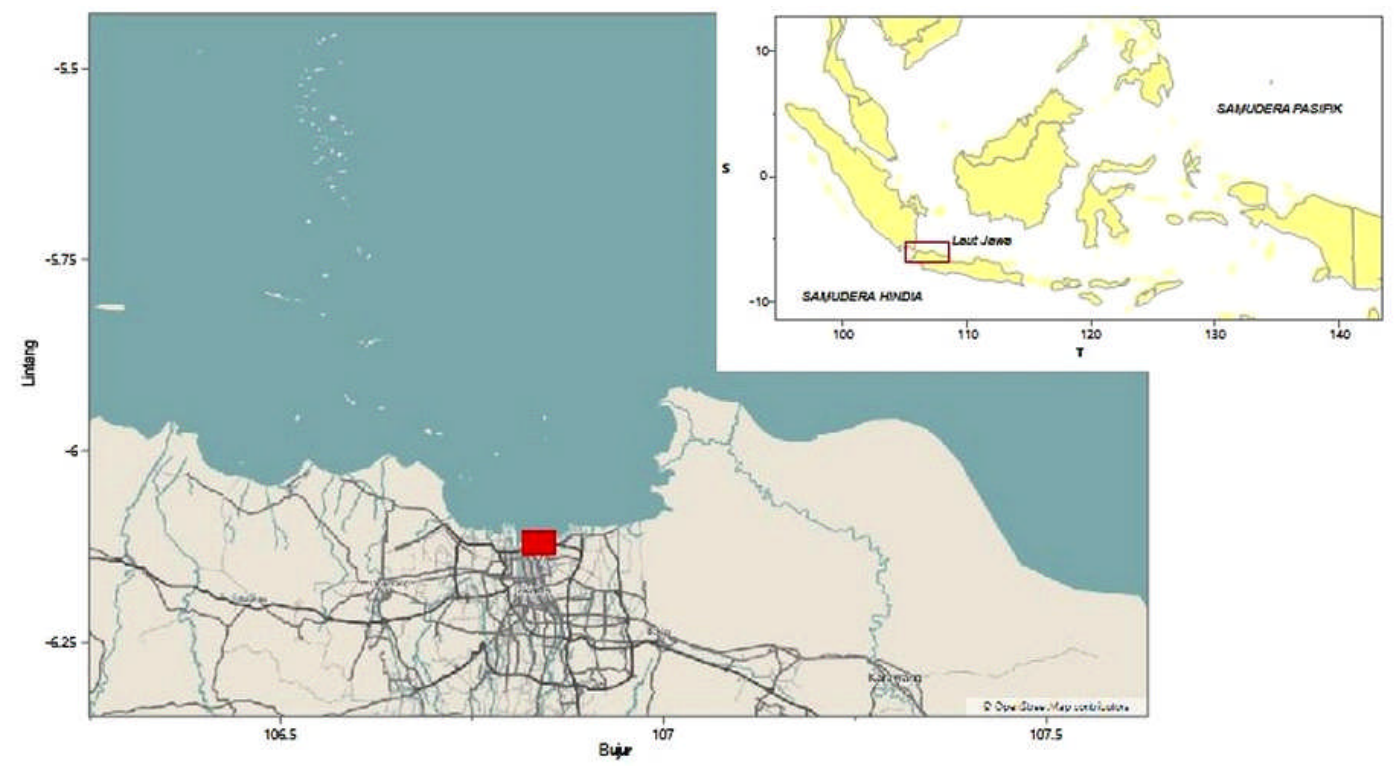

Gambar 1. Lokasi pengambilan sampling biologi ikan petek.

Figure 1. Location of sampling biology of pony fish.

Metode transformasi log-alometrik (Brodziak, 2012)

Model yang umum digunakan untuk menggambarkan hubungan panjang (L) dan berat (W):

$W=a L^{b}$

Dalam persamaan (1), nilai parameter a dan b diestimasi dengan adanya data panjang dan berat. Parameter a adalah dapat dihitung dari regresi linear tranformasi-log pada berat dan panjang ikan. Persamaan hubungan panjang berat ini dirubah dengan menerapkan logaritma natural, maka persamaan regresi linier memprediksi logaritma berat sebagai fungsi dari logaritma dari panjang. Model linear regresi dapat cocok digunakan untuk mengamati panjangberat data menggunakan metode kemungkinan maksimum untuk mendapatkan estimasi maksimum likelihood (MLEs) parameter pertumbuhan.

Tujuan dari tulisan ini adalah untuk memberikan informasi komposisi jenis ikan yang tertangkap, sebaran ukuran dan hubungan panjang-berat ikan petek di Teluk Jakarta dengan menggunakan metode regresi log-alometrik.

\section{BAHANDANMETODE}

Penelitian dilakukan secara bulanan selama periode April-Desember 2014 di lokasi pendaratan ikan Cilincing Jakarta Utara (Gambar 1). Sampling dilakukan secara berkala dengan melakukan pengukuran panjang total, panjang cagak dan panjang standar serta berat individu ikan petek hasil tangkapan jaring rampus, bagan dan sero. Semua jenis ikan petek yang tertangkap diidentifikasi jenisnya, dengan mengacu Sainsbury, et al. (1985).

koefisien regresi sedangkan parameter $\mathrm{b}$ adalah parameter bentuk tubuh spesies ikan.

Pengukuran panjang berat jenis ikan diasumsikan terdiri dari n pengukuran dari individu ikan, maka data set panjang berat $(\mathrm{D})=\{(\mathrm{W} 1, \mathrm{~L} 1),(\mathrm{W} 2, \mathrm{~L} 2), \ldots,(\mathrm{Wk}, \mathrm{Lk})\}$ dimana Wk adalah berat ikan ke-k dan Lk adalah panjang ikan ke-k. Persamaan transformasi dengan menerapkan logaritma natural pada persamaan (1), maka persamaan merupakan 
persamaan regresi linear untuk memprediksi logaritma berat sebagai fungsi dari logaritma panjang ikan. Persamannya adalah:

$\log W=\log a+b \cdot \log L \equiv b 0+b 1 \cdot \log L+\varepsilon$

Estimasi kemungkinan maksimum dari b1 adalah:

$b 1=\frac{\sum_{k}^{n}\left(\log L_{k}-E[\log L]\right) \cdot\left(\log W_{k}-E[\log W]\right)}{\sum_{j=1}^{n}(\log L j-E[\log L])^{2}}$

Nilai koefisien determinasi untuk analisis regresi $\left(\mathrm{R}^{2}\right)$ adalah:

$$
R^{2}=1-\frac{\sum_{k=1}^{n} \varepsilon_{k}^{2}}{\sum_{j=1}^{n}(\log W j-E[\log W])^{2}}
$$

Nilai $\mathrm{R}^{2}$ memberikan ukuran goodness-of-fit model regresi, semakin besar nilai $\mathrm{R}^{2}$ maka model regresi yang dihasilkan semakin menggambarkan kondisi di lapangan.

Menentukan sifat pertumbuhan ikan dilakukan dengan melakukan uji t pada nilai b yang diperoleh atau dengan membandingkan nilai $P$ value dengan nilai taraf nyatanya. Dalam kasus ini nilai taraf nyata yang dipergunakan adalah 0,05. Apabila nilai $\mathrm{b}=3$, maka dikatakan bahwa pertumbuhan ikan bersifat isometrik, sedangkan $b \neq 3$, maka pertumbuhan ikan bersifat allometrik. Jenis sifat pertumbuhan allometrik dibedakan menjadi dua, yaitu:

a) bila $b>3$ allometrik positif

b) bila $b<3$ allomterik negatif .

Sifat pertumbuhan ikan petek ini dapat diketahui dengan uji t dua arah. Hipotesis yang digunakan dalam uji t ini adalah :

Ho $: b=3$

$\mathrm{H} 1: \mathrm{b} \neq 3$

Pengambilan keputusan dalam uji ini adalah dengan membandingkan hasil $\mathrm{T}$ hitung dengan $\mathrm{T}$ tabel pada selang kepercayaan $95 \%$. Wilayah penolakan Ho terletak pada

$$
\begin{aligned}
& t<-t_{(d b, \alpha / 2)} \quad \text { dan } t>t_{(d b ; \alpha / 2)} \text { Jika } \\
& -t_{(d b, \alpha / 2)}<t<t_{(d b ; \alpha / 2)} \text { maka sifat pertumbuhan ikan }
\end{aligned}
$$

petek bersifat isometrik, sedangkan jika $t \leq-t_{(d b, \alpha / 2)}$ atau $t \geq t_{(d b ; \alpha / 2)}$ maka pertumbuhan ikan petek bersifat alometrik. Apabila sampel besar ( $\mathrm{n}>30)$ maka digunakan uji Z, dengan wilayah penolakan Ho adalah $z \leq-z_{\alpha / 2 \text { dan }} z \geq z_{\alpha / 2}$.
Ukuran panjang pertama kali tertangkap (Lc) dan ukuran panjang pertama matang gonad (Lm)

Metode penentuan ukuran pertama kali ikan tertangkap (Lc) dilakukan dengan menggunakan metode kantung berlapis (covered cod-end method). Hasil perhitungan tersebut membentuk kurva logistik baku yang berbentuk kurva sigmoid (Beverton \& Holt, (1957) dalam Sparre \& Venema, (1998)). Adapun persamaan matematis untuk menghitung ukuran pertama kali tertangkap adalah sebagau berikut:

$$
S L=\frac{1}{1+\exp (S 1-S 2 * L}
$$

Dengan $S L$ adalah selektivitas, $L$ adalah interval titik tengah selang kelas panjang, dan $S 1, S 2$ adalah konstanta.

Selanjutnya dilakukan perhitungan panjang infinitif $(\mathrm{L} \infty)$ yang diperoleh dengan cara (Sparre \& Venema, 1999):

$L \infty=\frac{1}{0,95} * L_{\max }$

Selama penelitian tidak dilakukan pengamatan gonad, sehingga untuk mengetahui ukuran pertama matang gonad (Lm) ikan petek ini menggunakan referensi hasil kajian yang telah ada.

\section{HASIL DAN BAHASAN \\ Hasil}

\section{Jenis Ikan Petek yang Tertangkap di Teluk Jakarta}

Komposisi jenis ikan petek yang tertangkap di perairan Teluk Jakarta pada 2014 tercatat sebanyak tiga genera dengan tujuh jenis spesies petek. Ketiga genera tersebut adalah Leiognathus, Secutor dan Gazza. Genera Leiognathus terdiri atas lima jenis (L. splendens, $L$. equulus, L. bindus, L. decorus dan L. fasciatus, genera Secutor hanya terdiri dari satu jenis (Secutor ruconius), begitu pula genera Gazza juga hanya terdapat satu jenis ikan (Gazza achlamys).

Komposisi jenis ikan petek yang tertangkap di Teluk Jakarta didominasi oleh jenis L. equulus dengan komposisi sebesar 64,4\% dari seluruh jenis ikan petek yang tercatat. Komposisi terbesar kedua adalak jenis L. splendens dan G. achlamys yang mencapai lebih dari $11 \%$. Kemudian disusul dengan jenis $L$. fasciatus $(8,4 \%)$, L. decorus $(3,2 \%)$, $S$. ruconius $(1,5 \%)$ dan yang terendah adalah jenis $L$. bindus yang hanya sekitar 0,3\% (Gambar 2). 


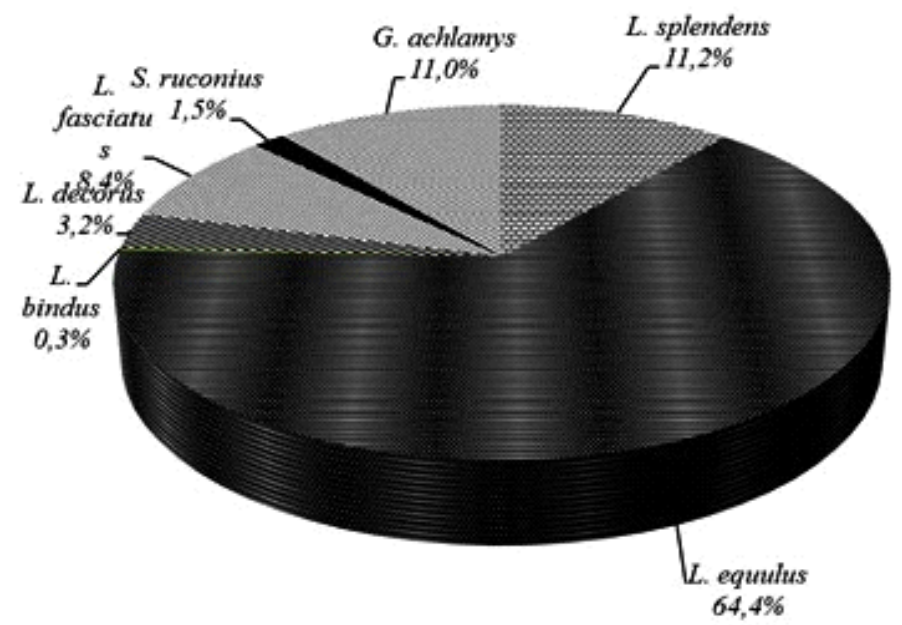

Gambar 2. Komposisi jenis ikan petek di Teluk Jakarta.

Figure 2. Species composition of pony fishes in Jakarta bay.

\section{Sebaran Ukuran Ikan Petek}

Leiognathus equulus merupakan spesies yang paling dominan tertangkap di perairan Teluk Jakarta. Panjang cagaknya (FL) berkisar antara 2,20 - 21,20 cm dan ukuran rata-rata sekitar $7,09 \mathrm{~cm}$. Ukuran ikan petek yang paling kecil adalah $S$. ruconius dengan kisaran ukuran antara 3,20
$-6,50 \mathrm{~cm}$. Rata-rata ukuran ikan petek yang tertangkap di Teluk Jakarta cenderung beragam, dengan kisaran nilai ratarata ukuran panjang terendah adalah $5,36 \mathrm{~cm}$ untuk jenis $S$. ruconius dan rata-rata ukuran panjang tertinggi hanya berkisar $9,00 \mathrm{~cm}$ pada jenis $L$. decorus, $L$. bindus dan $G$. achlamys (Gambar 3).

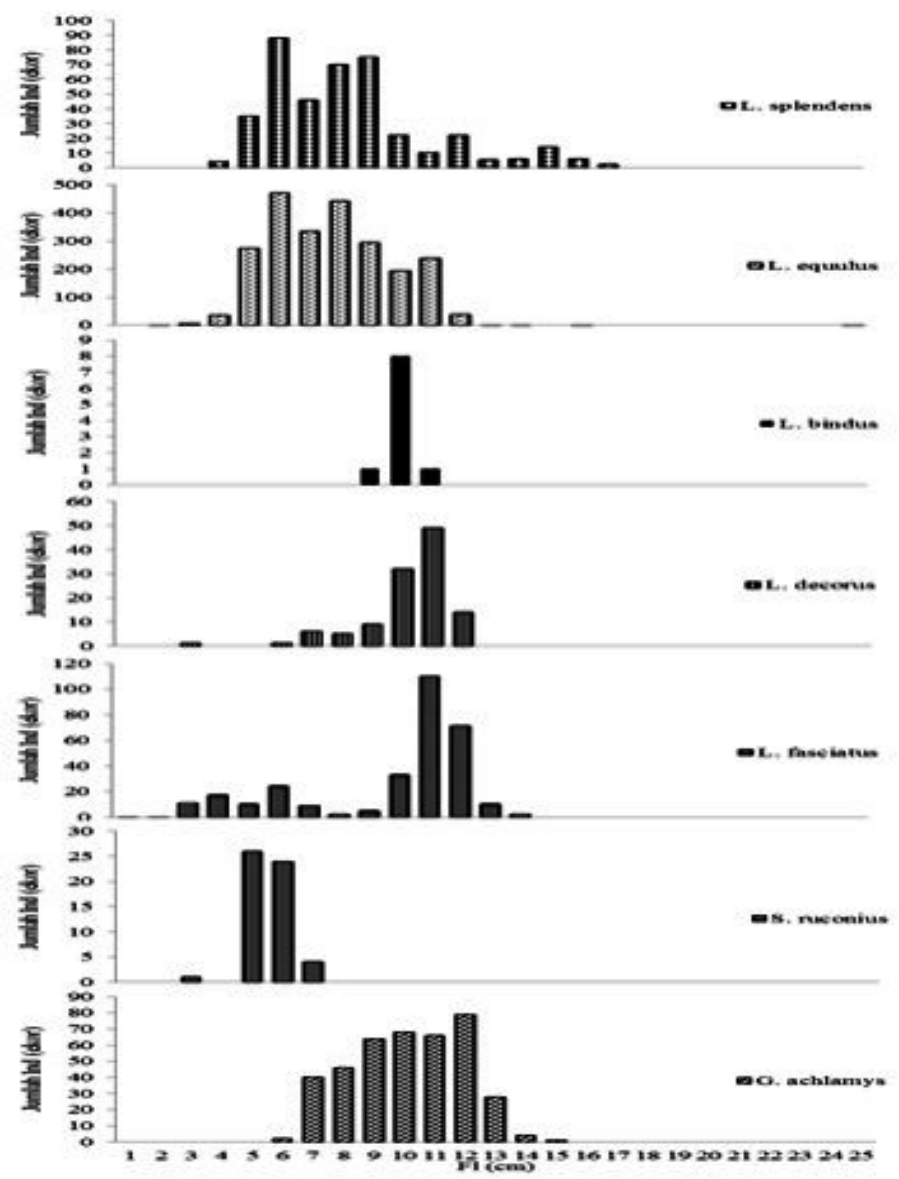

Gambar 3. Sebaran ukuran panjang beberapa jenis ikan petek. Figure 3. Length distribution of some pony fishes. 


\section{Hubungan Panjang Berat dengan Model Tranformasi Log-Alometrik}

Analisis hubungan panjang dan berat dengan model tranformasi log-alometrik menggunakan data panjang total dan berat ikan beberapa spesies ikan petek. Analisis ini digunakan untuk melihat pola pertumbuhan individu ikan petek di perairan Teluk Jakarta. Hubungan panjang berat ikan petek di Teluk Jakarta disajikan pada Tabel 1.

Hasil analisis hubungan panjang berat dengan metode kemungkinan maksimum menunjukkan bahwa nilai $\widehat{b}$ dari beberapa jenis ikan petek bervariasi. Nilai $\hat{b}$ terendah terdapat pada jenis S. ruconius dengan nilai 2,571, sedangkan nilai $\hat{b}$ terbesar adalah ikan $L$. decorus dengan nilai 3,222 (Tabel 1). Nilai konstanta determinasi dari semua jenis ikan petek yang dikaji memiliki nilai konstanta determinasi yang tinggi dengan nilai lebih besar dari $87,5 \%$. Sifat pertumbuhan dari tiap jenis ikan petek ditentukan dengan uji z dikarenakan jumlah sampel yang digunakan lebih besar dari 30 ekor. Hasil uji z yang dilakukan terhadap nilai b pada taraf nyata 0,05 pada keenam jenis ikan petek, menunjukkan bahwa nilai z hitung berada didaerah penolakan Ho. Z hitung yang diperoleh memiliki nilai yang lebih besar dari nilai $\mathrm{z}$ tabel dan lebih kecil dari -z tabel, serta $P$ value memiliki nilai yang lebih kecil dari nilai taraf nyatanya. Kondisi ini menunjukkan bahwa jenis ikan petek yang bersifat alometrik negatif adalah ikan L. splendens, L. equulus, S. ruconius dan $G$. achlamys. Sedangkan untuk ikan $L$. decorus dan $L$. fasciatus bersifat alometrik positif (Tabel 2).

Tabel 1. Hubungan panjang berat ikan petek di TPI Cilincing, Teluk Jakarta

Table 1. Length weight of pony fish in the Cilincing landing port, Jakarta bay

\begin{tabular}{ccccccc}
\hline Jenis/Species & $\hat{b}$ & std $\bar{b}]$ & $|\hat{a}|$ & std $[\bar{a}]$ & $\left|R^{2}\right|$ & Pvalue \\
\hline L. splendens & 2,976 & 0,024 & 0,212 & 1,002 & 0,97 & 0,00000 \\
L. equulus & 2,848 & 0,013 & 0,237 & 1,002 & 0,88 & 0,00000 \\
L. decorus & 3,222 & 0,064 & 0,157 & 1,003 & 0,99 & $5,41 \mathrm{E}-80$ \\
L. fasciatus & 3,081 & 0,016 & 0,184 & 1,001 & 0,99 & 0,00000 \\
S. ruconius & 2,571 & 0,201 & 0,265 & 1,013 & 0,99 & $8,08 \mathrm{E}-18$ \\
G. achlamys & 2,936 & 0,053 & 0,209 & 1,004 & 0,88 & $3,1 \mathrm{E}-281$ \\
\hline \hline
\end{tabular}

Tabel 2. Statistik uji-z pada nilai b jenis ikan petek di Teluk Jakarta

Table 2. Z-test statistic of $b$ value of pony fish in Jakarta bay

\begin{tabular}{ccccrrll}
\hline \hline Jenis/Species & $\mathbf{n}$ & $\mathbf{b}$ & $z_{\text {hitung }}$ & $-z_{\alpha} / 2$ & $z_{\alpha / 2}$ & Keputusan & Sifat \\
\hline \hline L. splendens & 405 & 2,976 & $-19,9$ & $-1,96$ & 1,96 & Tolak Ho & alometrik negatif \\
L. equulus & 2332 & 2,848 & $-580,9$ & $-1,96$ & 1,96 & Tolak Ho & alometrik negatif \\
L. decorus & 117 & 3,222 & 37,3 & $-1,96$ & 1,96 & Tolak Ho & alometrik positif \\
L. fasciatus & 306 & 3,081 & 86,6 & $-1,96$ & 1,96 & Tolak Ho & alometrik positif \\
S. ruconius & 55 & 2,571 & $-15,8$ & $-1,96$ & 1,96 & Tolak Ho & alometrik negatif \\
G. achlamys & 398 & 2,936 & $-24,1$ & $-1,96$ & 1,96 & Tolak Ho & alometrik negatif \\
\hline \hline
\end{tabular}

Hasil tangkapan ikan petek di Teluk Jakarta cenderung beragam kecuali untuk jenis $S$. ruconius. Hal ini ditunjukkan dengan nilai standar deviasi yang cenderung tinggi, yaitu 0,20 sedangkan untuk jenis ikan yang lain memiliki nilai standar deviasi yang rendah, yaitu kurang dari 0,064. Berdasarkan hasil metode MLE diperoleh nilai koefisien pertumbuhan (b) yang sama dengan nilai koefisien estimasi tranformasi logaritmanya. Hal ini menunjukkan bahwa tidak adanya koreksi bias dalam perhitungan.

\section{Ukuran Panjang Pertama Kali Tertangkap (Lc)}

Ukuran panjang pertama kali tertangkap dari beberapa ikan Petek di perairan Teluk Jakarta adalah 7,9 cm, 7,7 cm, $7,6 \mathrm{~cm}, 8,1 \mathrm{~cm}$ dan $8,9 \mathrm{~cm}$ untuk ikan L. splendens, $L$. equulus, L. decorus, L. fasciatus dan G. achlamys (Gambar 4). Berdasarkan perhitungan $L_{\infty}$ dan setengah $L_{\infty}$ maka ukuran ikan yang tertangkap masih lebih besar dari panjang $1 / 2 \mathrm{~L}_{\infty}$, kecuali untuk jenis L. equulus (Tabel 3).

Meskipun ukuran pertama kali ikan tertangkap masih di atas panjang setengah infinitifnya, akan tetapi ukuran ikan petek yang tertangkap ini masih dibawah dari ukuran panjang pertama kali matang gonad (Lc < Lm) (Tabel 3). Ukuran panjang pertama kali matang gonad dalam penelitian ini menggunakan hasil kajian di lokasi lain, dikarenakan selama penelitian tidak dilakukan pengukuran kematangan gonad. Menurut hasil kajian Meyer, et al. (2003), ukuran Lm pada beberapa lokasi tidak berbeda signifikan. Kondisi ukuran pertama tertangkap dibawah dari ukuran pertama matang gonad ini merupakan kondisi yang tidak diharapkan dalam kegiatan penangkapan selanjutnya. Kondisi ini mengindikasikan bahwa ikan-ikan yang tertangkap belum mengalami matang gonad sehingga ikan tersebut tidak memiliki kesempatan untuk bereproduksi. 
Tabel 3. Panjang pertama tertangkap, panjang infinitif, panjang maksimal dan panjang pertama matang gonad (Lc, $\mathrm{L}$, Lm) ikan Petek

Table 3. $\quad$ Length at first capture, length infinity, maximum of length and length at first mature of ponyfish

\begin{tabular}{lcccl}
\hline Jenis/Species & Lc $(\mathbf{c m})$ & $\mathbf{L}_{\infty}(\mathbf{c m})$ & Lmax $(\mathbf{c m})$ & \multicolumn{1}{c}{$\mathbf{L m}(\mathbf{c m})$} \\
\hline \hline L. splendens & 7,9 & 15,6 & 14,8 & $7,5-7,9$ (Abraham et al., 2011) \\
L. equulus & 7,7 & 22,3 & 21,2 & 8.8 (Novitriana et al., 2004) \\
L. decorus & 7,6 & 11,5 & 10,9 & 9,2 (http://www.fishbase.org) \\
L. fasciatus & 8,1 & 12,6 & 12,0 & 13,176 (Harlan, 2014; 13,6 (Widjayana et al., 2015) \\
G. achlamys & 8,9 & 13,3 & 12,6 & 13,176 (Harlan, 2014; 13,6 (Widjayana et al., 2015) \\
\hline
\end{tabular}
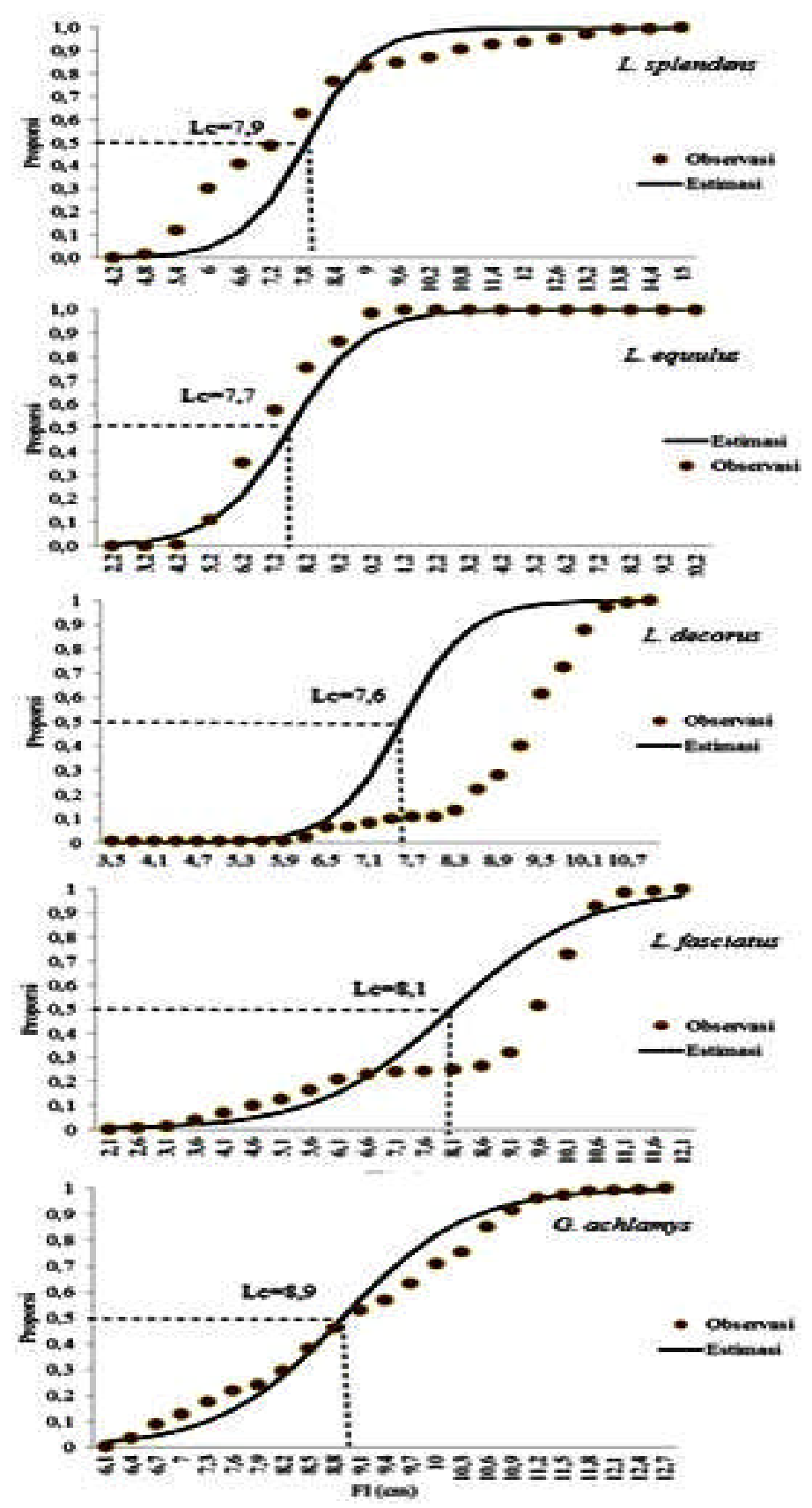

Gambar 4. Kurva ukuran panjang pertama kali tertangkap beberapa jenis ikan petek.

Figure 4. Length at first capture of some pony fishes. 


\section{BAHASAN}

Ikan petek merupakan jenis demersal yang banyak tertangkap di perairan Indonesia, khususnya di Laut Jawa mencapai 60\% dari total tangkapan (Badruddin, 1988; Sumiono et al., 2002). Di Indonesia ditemukan 12 spesies ikan petek yang tersebar di perairan dangkal, atau kurang dari 40 m (Widodo, 1976). Meniek et al. (1988) mengatakan bahwa ikan petek yang dominan di Laut Jawa yang tertangkap oleh jaring trawl adalah jenis Leiognathus splendens. Tahun 2005 di perairan barat sumatera tercatat sebanyak delapan spesies ikan petek (L. bindus, $L$. splendens, L. leusiscus, L. equulus, S. ruconius, G minuta, L. smithursti dan S. insidiator) sedangkan pada 2006 komposisi jenis ikan petek yang tertangkap lebih banyak yaitu 13 spesies (Wedjatmiko, 2007) dan 15 jenis ikan petek yang berbeda ditemukan di perairan Jawa Timur (Wiadnya etal., 2014).

Komposisi jenis ikan petek yang tertangkap di Teluk Jakarta selama penelitian terdiri atas jenis L. equulus, $L$. splendens, G. achlamys, L. fasciatus, L. decorus, S. ruconius dan L. bindus. Komposisi jenis ini didominasi oleh jenis L. equulus (Gambar 2). Kondisi ini serupa dengan hasil tangkapan di Wilayah perairan pesisir Kendal, bahwa dominansi hasil tangkapan ikan petek adalah Leiognathus splendens dan Leiognathus equulus (Budiman, 2006). Berbeda halnya kondisi di perairan barat Sumatera pada 2005 dan 2006, dimana pada kedua tahun ini L. bindus merupakan jenis yang paling dominan (Wedjatmiko, 2007). Perbedaan ini diduga karena perbedaan lokasi penangkapan dan kondisi lingkungan yang berbeda. Pada 2005 dan 2006 penangkapan dilakukan di perairan barat Sumatera sedangkan kajian ini dilakukan di wilayah Teluk Jakarta. Disamping itu pula kondisi perairan di barat Sumatera memiliki lingkungan yang lebih bagus dari lingkungan di Teluk Jakarta. Perbedaan jenis ikan petek ini juga terjadi di Perairan Laut Cina Selatan, yaitu di perairan Pulau Sibu-Tinggi, Johor Malaysia. Jeni ikan petek yang tertangkap di perairan ini adalah S. insidiator, G. rhombea, L. oblongus, L. bindus, L. daura, L. equulus, L. decorus, $L$. smithursti dan L. jonesi. Jenis ini didominasi oleh L. jonesi dan L. oblongus (Mazlan \& Seah, 2006).

Rata-rata ukuran ikan petek yang tertangkap di Teluk Jakarta cenderung beragam, dengan kisaran panjang 2,20$21-20 \mathrm{~cm}$. Jenis ikan petek yang terkecil adalah $S$. ruconius dengan panjang rata-rata tertangkap sekitar $5,36 \mathrm{~cm}$. Sedangkan jenis dengan ukuran yang besar adalah $L$. decorus, L. bindus dan G. achlamys dengan panjang ratarata sekitar 9,00 cm (Gambar 3). Ukuran panjang petama kali tertangkap dari ikan petek di Teluk Jakarta ini cenderung berukuran kecil bila dibandingkan dengan ukuran ikan petek di perairan Barat Sumatera. Jenis ikan petek yang memiliki ukuran kecil dan besar juga berbeda pada kedua perairan tersebut. Di perairan Barat Sumatera ukuran ikan petek yang paling kecil adalah $L$. daura dengan kisaran ukuran 6,0 - 6,5 cm, sedangkan jenis petek $L$. fasciatus, $L$. smithursti dan L.equulus, merupakan jenis ikan petek yang besar dengan ukuran rata-rata lebih besar dari FL 15,0 cm (Wedjatmiko, 2007). Rata-rata ukuran panjang ikan petek khususnya L. equulus di Teluk Jakarta selama penelitian juga menunjukkan ukuran yang lebih kecil bila dibandingkan dengan ukuran ikan petek hasil penelitian sebelumnya. Genisa (1999) menyatakan bahwa ukuran ikan petek dapat mencapai ukuran $22 \mathrm{~cm}$. Begitu pula hasil penelitian tahun 2010 menunjukkan ukuran panjang ikan petek mencapai $13,4 \mathrm{~cm}$ dan ukuran dominan tertangkap pada kisaran lebih dari $8 \mathrm{~cm}$ (Pratiwi, 2011). Variasi ukuran antara spesies yang sama dari berbagai lokasi geografis ini dipengaruhi oleh faktor lingkungan seperti nutrisi, makanan, ketersediaan dan musim dari tahun, yang juga pertumbuhan ikan tersebut (Jennings et al., 2001).

Sifat pertumbuhan ikan petek dilihat dari hasil nilai $b$ yang diperoleh dengan membandingkan nilai $b$ tersebut dengan nilai 3. Untuk mendapatkan adanya perbedaan yang nyata nilai b ini dengan nilai 3 dilakukan dengan uji z dua arah. Uji z ini dilakukan karena jumlah sampel yang digunakan melebihi 30 ekor. Hasil perhitungan uji z diperoleh nilai $z$ hitung yang berada pada daerah penolakan Ho (Tabel 2). Sehingga berdasarkan perhitungan nilai $b$ pada semua jenis ikan petek, diperoleh bahwa jenis ikan $L$. splendens, L. equulus, S. ruconius dan G. achlamys bersifat alometrik negatif, sedangkan jenis ikan $L$. decorus dan $L$. fasciatus bersifat alometrik positif. Hasil ini sejalan dengan hasil kajian pada tahun 2010 yang diperoleh pola pertumbuhan ikan petek (L. equulus) adalah allometrik negatif (Pratiwi, 2011). Begitu pula hasil penelitian oleh Chaerrudin (1977) di Teluk Jakarta menyatakan bahwa pola pertumbuhan ikan petek bersifat allometrik. Kondisi ini juga diperkuat dari hasil penelitian di perairan Banten bahwa hubungan panjang berat ikan petek pada jantan maupun betina, pola pertumbuhannya bersifat allometrik negatif dimana pertambahan panjang lebih cepat dibandingkan dengan pertambahan beratnya (Prihatiningsih et. al. 2015) . Pertumbuhan ikan petek bersifat allometrik ini juga dinyatakan oleh Simanjuntak (2010) di lokasi Blanakan, Labuan dan pelabuhan Ratu. Di perairan Selat Malaka pola pertumbuhan ikan L. splendens bersifat allometrik sementara di perairan Teluk Labuan memiliki pola pertumbuhan isometrik (Saadah, 2000). Perbedaan pola pertumbuhan sebagai akibat dari pengaruh lingkungan seperti suhu, jumlah dan kualitas makanan yang dicerna dan umur (Moyle \& Cech 1998).

Ukuran panjang pertama tertangkap dan informasi tentang panjang pertama kali matang gonad merupakan hal yang penting untuk dipelajari. Kedua informasi ini dapat memberikan gambaran kondisi keberlanjutan sumberdaya 
ikan. Dari hasil penelitian diperoleh bahwa ukuran panjang pertama kali tertangkap dari ikan petek memiliki ukuran yang lebih kecil dari ukuran pertama matang gonad. Kondisi ini mencerminkan bahwa ikan yang tertangkap tersebut belum mengalami pemijahan atau belum melakukan rekruitmen. Kondisi penangkapan yang baik untuk menunjang proses rekuitmen adalah ketika ukuran panjang individu yang ditangkap sama dengan atau lebih besar dengan ukuran pertama kali matang gonad (Lm). Ukuran ikan hasil tangkapan cenderung berukuran kecil merupakan indikasi tingginya eksploitasi pada sumberdaya tersebut. Hal ini sesuai dengan pernyataan Stevens et al. (2000) yang menyatakan bahwa eksploitasi tinggi mengakibatkan populasi didominasi oleh ikan kecil dan kematangan gonad yang lebih awal .

\section{KESIMPULAN}

Jenis ikan petek yang tertangkan di perairan Teluk Jakarta adalah Leiognathus. splendens, L. equulus, $L$. bindus, L. decorus, L. fasciatus, Secutor ruconius dan Gazza achlamys. Hasil tangkapan dominan adalah jenis $L$. equulus. Hasil tangkapan semua jenis ikan petek cenderung beragam dan telah terjadi indikasi penurunan ukuran tangkapan. Model tranformasi log-alometrik menghasilkan pola pertumbuhan ikan petek bersifat alometrik. Jenis $L$. splendens, L. equulus, S. ruconius dan G. achlamys bersifat alometrik negatif, sedangkan jenis ikan $L$. decorus dan $L$. fasciatus bersifat alometrik positif. Ukuran panjang pertama kali tertangkap dari ikan petek di Teluk Jakarta berada dibawah ukuran panjang pertama matang gonad $(\mathrm{Lc}<\mathrm{Lm})$ yang mengindikasikan perikanan petek mengarah pada growth overfishing.

\section{PERSANTUNAN}

Tulisan ini merupakan kontribusi dari kegiatan riset "Kajian Perikanan dan Lingkungan di Teluk Jakarta. Terima kasih kepada Pusat Penelitian Pengelolaan Perikanan dan Konservasi Sumberdaya Ikan yang telah membiayai kegiatan selama penelitian. Ucapan terima kasih juga disampaikan kepada para peneliti senior dan pemangku kepentingan perikanan di Teluk Jakarta atas kontribusinya dalam memberikan informasi terkait perikanan ikan Petek ini.

\section{DAFTAR PUSTAKA}

Abraham, K.J., Murty, V.S.R., \& Joshi, K.K. (2011). Reproductive biology of Leiognathus splendens (Cuvier) from kochi, South-west coast of India. Indian J.fish. 58 (3), 23-31.

Badruddin, M. (1988). Parameter stok dan potensi penangkapan ikan petek (Leiognathidae) di perairan pantai utara Jawa Tengah. Jurnal Penelitian Perikanan Laut. 47, 87-95.

Brodziak, J. (2012). Fitting length-weight relationships with linear regression using the log-transformed allometric model with bias-correction. Pacific Islands Fish. Sci. Cent., Natl. Mar. Fish. Serv., NOAA, Honolulu. HI 968222396.

Budiman. (2006). Analisis sebaran ikan demersal sebagai basis pengelolaan sumberdaya pesisir di Kabupaten Kendal. Tesis. Program Studi Magister Manajemen Sumberdaya Pantai, Universitas Diponegoro, Semarang.

Burhanuddin, Martosewojo, S., \& Djamali, A. (1980). Ikanikan demersal di Perairan Teluk Jakarta. Teluk Jakarta Pengkajian Fisika, Kimia, Biologi dan Geologi Tahun 1975-1979 (pp.337-360). Jakarta: Lembaga Oseanologi Nasional, LIPI.

Chaerrudin, G. (1977). Studi pendahuluan tentang aspekaspek taksonomi, pertumbuhan dan pemijahan ikan petek (Leiognathus spp.) di Perairan Teluk Jakarta. Tesis. Program Studi Magister Perikanan, Universtas Lambung Mangkurat Afiliasi. Institut Pertanian Bogor.

Effendie, M.I. (1997). Biologi perikanan (p.163). Yogyakarta: Yayasan Pustaka Nusatama.

Harlan, N.H.R. (2014). Struktur populasi dan reproduksi ikan petek (Leiognathus spp.) Hasil Tangkapan di Pantai Selatan Tasikmalaya. Diambil dari UNPAD Repository website: http://repository.unpad.ac.id/ 19728/.

Genisa A.S. (1999). Pengenalan jenis-jenis ikan laut ekonomi penting di Indonesia. Majalah Ilmiah Semi Populer. Oseana. Volume XXIV, Nomor 1 : 17-38.

Jennings, S., Kaiser, M.J., \& Reynolds, J.D. (2001). Marine Fisheries Ecology (p.435). Blackwell Science Publ. Oxford.

Kishakudan S.J., Reddy, P.S. (2012). Length-weight relationship in three spesies of silver bellies from Chennai coast. Indian J. Fish. 59(3), 65-68.

Mazlan, A.G., \& Seah, Y.G. (2006). Meristic and LengthWeight Relationship of Ponyfishes (Leiognathidae) in the Coastal Water of Pulau Sibu-Tinggi, Johor, Malaysia. Malays. Appl. Biol. 35(1), 27-35.

Meniek, M.D.P., \& Nugroho, D. (1988). Laju tangkap, sebaran dan kelimpahan ikan petek (Leiognathus 
splendens Cuv. 1829) di pantai utara Jawa. Jurnal Penelitian Perikanan Laut. 46, 55-61.

Meyer, K. A., Schill, D. J., Elle, F. S., \& Lamansky, Jr, J. A. (2003). Reproductive demographics and factors that influence length at sexual maturity of Yellowstone cutthroat trout in Idaho. Transactions of the American Fisheries Society. 132, 183-195.

Moyle, P.B., \& Cech, J.J.J.R. (1988). Fishes: An introduction to ichthyology (P.559). Prentice Hall, Englewood. New Jersey.

Novitriana, R., Ernawati, Y., \& Rahardjo, M.F. (2004). Aspek Pemijahan Petek, Leiognathus equulus, Forskal 1775 (Fam. Leiognathidae) di Pesisir Mayangan Subang, Jawa Barat. Jurnal Iktiologi Indonesia. 4(1): 7-13.

Pauly, D. (1977). The leiognathus (Teleostei) their spesies stock and fisheries in Indonesia, with notes on the biology of Leiognathus splendens. Mar. Res. In. Indonesia. 19, 73-93.

Pratiwi, E. (2011). Kajian stok dan analisis ketidakpastian hasil tangkapan sumberdaya ikan petek (Leiognathus equulus Forskal, 1874) di Perairan Teluk Jakarta. Skripsi. Departemen Manajemen Sumberdaya Perairan Fakultas Perikanan dan Ilmu Kelautan Institut Pertanian Bogor.

Prihatiningsih, Ratnawati, P. \& Taufik, M. (2015). Biologi Reproduksi dan Kebiasaan Makan Ikan Petek (Leiognathus splendens) di Perairan Banten dan Sekitarnya. Bawal. 6 (3), 1-8.

Saadah. (2000). Beberapa aspek biologi ikan petek (Leiognathus splendens Cuv.) di perairan Teluk Labuan, Jawa Barat. skripsi. Program Studi Manajemen Sumberdaya Perairan, Fakultas Perikanan dan Ilmu Kelautan, Institut Pertanian Bogor.

Sainsbury, K.J., P.J. Kailola and G.G. Leyland. (1985). Continental shelf fishes of the northern and northwestern Australia (p. 375). CSIRO Division of Fisheries
Research; Clouston \& Hall and Peter Pownall Fisheries Information Service, Canberra, Australia.

Simanjuntak, R.J. (2010). Keterkaitan Laju Eksploitasi Dengan Keragaan Pertumbuhan dan Reproduksi Ikan Petek Leiognathus equulus (Forsskal , 1775) Famili Leiognathidae. Skipsi. Departemen Manajemen Sumberdaya Perairan, Fakultas Perikanan dan Ilmu Kelautan, Institut Pertanian Bogor.

Stevens J.D., Bonfil, R., Dulvy, N.K., \& Walker, P.A. (2000). The effect of fishing on shark, rays, and chimaeras (Chondrichthyans), an the implications for marine ecosystems. ICES, Journal of Marine Science. 57, 476494.

Sumiono, B., Sudjianto, Soselisa, Y., \& Murtoyo, T.S. (2002). Laju tangkap dan komposisi jenis ikan demersal dan udang yang tertangkap trawl pada musim timur di perairan utara Jawa Tengah. J.Lit.Perikan.Ind. Edisi Sumber Daya dan Penangkapan. 8 (4), 15-21.

w w w. f i s h b a s e. org/R e p r od u c t i o n / MaturityList.php?ID=4809.

Wedjatmiko. (2007). Komposisi ikan petek (Leiognathidae) di Perairan Barat Sumatra. Jurnal lktiologi Indonesia. 7(1), 9-14.

Wiadnya, D.G.R., Widodo, Marsoedi, Kusuma, W.E., Setyohadi, D., \& Soemarno. (2014). Morpho-species of common Silverbellies (Family: Leiognathidae) found in East Java's Coastal Sea, Indonesia. J. Bio. \& Env. Sci.5(2), 107-121.

Widodo. (1976). A Check list of the demersal spesies in the Java Sea. Special report No.I. Contribution of Demersal Fish Project. MRIF. Jakarta.

Widjaya A.O., Solihin, A., \& Saputra, S.W. (2015). Beberapa Aspek Biologi Ikan Petek (Leiognathus sp.) yang Tertangkap dengan Cantrang dan Arad di TPI Tawang, Kabupaten Kendal. Diponegoro Journal of Maquares. 4(3), 222-229. 